\title{
AAPS PharmSciTech \\ Formulation screening and freeze-drying process optimization of Ginkgolide B lyophilized powder for injection \\ --Manuscript Draft--
}

\begin{tabular}{|c|c|}
\hline Manuscript Number: & AAPSPT-D-17-00280R2 \\
\hline Full Title: & $\begin{array}{l}\text { Formulation screening and freeze-drying process optimization of Ginkgolide B } \\
\text { lyophilized powder for injection }\end{array}$ \\
\hline Article Type: & Research Article \\
\hline Section/Category: & $\begin{array}{l}\text { NOT APPLICABLE (Choose this section if you have NOT been invited to submit a } \\
\text { manuscript) }\end{array}$ \\
\hline Keywords: & $\begin{array}{l}\text { Ginkgolide B, formulation screening, freeze-drying process optimization, collapse } \\
\text { temperature }\end{array}$ \\
\hline Corresponding Author: & $\begin{array}{l}\text { Ying YU } \\
\text { China Pharmaceutical University } \\
\text { Nanjing, Jiangsu CHINA }\end{array}$ \\
\hline \multicolumn{2}{|l|}{$\begin{array}{l}\text { Corresponding Author Secondary } \\
\text { Information: }\end{array}$} \\
\hline Corresponding Author's Institution: & China Pharmaceutical University \\
\hline \multicolumn{2}{|l|}{$\begin{array}{l}\text { Corresponding Author's Secondary } \\
\text { Institution: }\end{array}$} \\
\hline First Author: & Ying YU \\
\hline \multicolumn{2}{|l|}{ First Author Secondary Information: } \\
\hline \multirow[t]{3}{*}{ Order of Authors: } & Ying YU \\
\hline & Daichun Liu \\
\hline & Federico Galvanin, Ph.D \\
\hline
\end{tabular}

Order of Authors Secondary Information:

Manuscript Region of Origin:

Abstract:

Suggested Reviewers:

Opposed Reviewers:

\section{CHINA}

The purpose of this study was to prepare ginkgolide B (GB) lyophilized powder for injection with excellent appearance and stable quality through a formulation screening and by optimizing the freeze-drying process. Cremophor EL as a solubilizer, PEG 400 as a latent solvent and mannitol as an excipient were mixed to increase the solubility of $\mathrm{GB}$ in water of more than 18 times. Formulation screening was conducted by orthogonal design where the content of GB in the solution before lyophilization and reconstitution time after lyophilization were the two evaluation indexes. The optimized formulations were GB in an amount of $2 \mathrm{mg} / \mathrm{ml}$, Cremophor EL in an amount of $16 \%$ $(\mathrm{v} / \mathrm{v})$, PEG 400 in an amount of $9 \%(\mathrm{v} / \mathrm{v})$, mannitol in an amount of $8 \%(\mathrm{w} / \mathrm{v})$, and the solution $\mathrm{pH}$ of 6.5. Through 4 single factor experiments (GB adding order, preparation temperature of GB solution, adding amount and adsorption time of activated carbon), the preparation process of GB solution was confirmed. The fully collapse temperature was determined by freeze-drying microscope, then the primary drying temperature was obtained. Thereby, the freeze-drying curve of GB lyophilized powder was initially identified. The freeze-drying process was optimized by orthogonal design, the qualified product appearance and residual moisture content were as two evaluation indexes. In these lyophilization process conditions, the products complied with relevant provisions of the lyophilized powders for injection, meanwhile, the reproducibility was satisfactory. Post-freezing annealing had no significantly beneficial effects on shortening the freezedrying cycle and improving the quality of GB lyophilized powder. 


\title{
Formulation screening and freeze-drying process optimization of Ginkgolide B lyophilized powder for injection
}

\author{
Daichun Liu ${ }^{1}$ Federico Galvanin ${ }^{2}$ Ying $\mathrm{Yu}^{1 *}$ \\ 1. School of Engineering, China Pharmaceutical University \\ 2. Department of Chemical Engineering, School of Engineering, University College \\ London
}

\section{Abstract}

The purpose of this study was to prepare ginkgolide B (GB) lyophilized powder for injection with excellent appearance and stable quality through a formulation screening and by optimizing the freeze-drying process. Cremophor EL as a solubilizer, PEG 400 as a latent solvent and mannitol as an excipient were mixed to increase the solubility of GB in water of more than 18 times (about from $2.5 \times 10^{-4} \mathrm{~mol} / \mathrm{L}(0.106 \mathrm{mg} / \mathrm{ml})$ to $\left.1.914 \mathrm{mg} / \mathrm{ml}\right)$. Formulation screening was conducted by orthogonal design where the content of GB in the solution before lyophilization (using external standard method of HPLC) and reconstitution time after lyophilization were the two evaluation indexes. The optimized formulations were GB in an amount of $2 \mathrm{mg} / \mathrm{ml}$, Cremophor EL in an amount of 16\% (v/v), PEG 400 in an amount of $9 \%(\mathrm{v} / \mathrm{v})$, mannitol in an amount of 8\% (w/v), and the solution $\mathrm{pH}$ of 6.5 . Through 4 single factor experiments (GB adding order, preparation temperature of GB solution, adding amount and adsorption time of activated carbon), the preparation process of GB solution was confirmed. The glass transition temperature of maximally GB freeze-concentrated solution was $-17.6^{\circ} \mathrm{C}$ through the electric resistance method. GB lyophilized powder began to collapse at $-14.0^{\circ} \mathrm{C}$, and the fully collapse temperature was $-13.0^{\circ} \mathrm{C}$, which were determined by freeze-drying microscope. When the collapse temperature was determined, then the primary drying temperature was obtained. Thereby, the freeze-drying curve of GB lyophilized powder was initially identified. The freeze-drying process was optimized by orthogonal design, the qualified product appearance and residual moisture content were as two evaluation indexes. The optimized process parameters and process were: (1) shelf temperature, decreased from room temperature to $-45.0^{\circ} \mathrm{C}$ at $0.5{ }^{\circ} \mathrm{C} / \mathrm{min}$ in two hours; (2) shelf temperature increased from $-45.0^{\circ} \mathrm{C}$ to $-25.0^{\circ} \mathrm{C}$ at $0.1{ }^{\circ} \mathrm{C} / \mathrm{min}$, maintaining 3 hours, and the chamber pressure held at $10 \mathrm{~Pa}$; (3) shelf temperature was increased from $-25.0^{\circ} \mathrm{C}$ to $-15.0^{\circ} \mathrm{C}$ at $0.1{ }^{\circ} \mathrm{C} / \mathrm{min}$, maintaining 4 hours, and the chamber pressure held at $10 \mathrm{~Pa}$; (4) shelf temperature 
was increased from $-15.0^{\circ} \mathrm{C}$ to $20.0^{\circ} \mathrm{C}$ at $1.0{ }^{\circ} \mathrm{C} / \mathrm{min}$, maintaining 4 hours, and the chamber pressure was raised up to $80 \mathrm{~Pa}$. In these lyophilization process conditions, the products complied with relevant provisions of the lyophilized powders for injection, meanwhile, the reproducibility was satisfactory. Post-freezing annealing had no significantly beneficial effects on shortening the freeze-drying cycle and improving the quality of GB lyophilized powder.

Key words: Ginkgolide B, formulation screening, freeze-drying process optimization, collapse temperature 
1 Formulation screening and freeze-drying process optimization

2 of Ginkgolide B lyophilized powder for injection

3

4

\section{Daichun Liu ${ }^{1}$ Federico Galvanin ${ }^{2}$ Ying $\mathrm{Yu}^{1 *}$}

1. School of Engineering, China Pharmaceutical University

2. Department of Chemical Engineering, School of Engineering, University College

\section{London}

\section{Abstract}

The purpose of this study was to prepare ginkgolide B (GB) lyophilized powder for injection with excellent appearance and stable quality through a formulation screening and by optimizing the freeze-drying process. Cremophor EL as a solubilizer, PEG 400 as a latent solvent and mannitol as an excipient were mixed to increase the solubility of GB in water of more than 18 times (about from $2.5 \times 10^{-4} \mathrm{~mol} / \mathrm{L}(0.106 \mathrm{mg} / \mathrm{ml})$ to $\left.1.914 \mathrm{mg} / \mathrm{ml}\right)$. Formulation screening was conducted by orthogonal design where the content of GB in the solution before lyophilization (using external standard method of HPLC) and reconstitution time after lyophilization were the two evaluation indexes. The optimized formulations were GB in an amount of $2 \mathrm{mg} / \mathrm{ml}$, Cremophor EL in an amount of $16 \%(\mathrm{v} / \mathrm{v})$, PEG 400 in an amount of $9 \%(\mathrm{v} / \mathrm{v})$, mannitol in an amount of $8 \%(\mathrm{w} / \mathrm{v})$, and the solution $\mathrm{pH}$ of 6.5 . Through 4 single factor experiments (GB adding order, preparation temperature of GB solution, adding amount and adsorption time of activated carbon), the preparation process of GB solution was confirmed. The glass transition temperature of maximally GB freeze-concentrated solution was $-17.6{ }^{\circ} \mathrm{C}$ through the electric resistance method. GB lyophilized powder began to collapse at $-14.0^{\circ} \mathrm{C}$, and the fully collapse temperature was $-13.0^{\circ} \mathrm{C}$, which were determined by freeze-drying microscope. When the collapse temperature was determined, then the primary drying temperature was obtained. Thereby, the freeze-drying curve of GB lyophilized powder was initially identified. The freeze-drying process was optimized by orthogonal design, the qualified product appearance and residual moisture content were as two evaluation indexes. The optimized process parameters and process were: (1) shelf temperature, decreased from room temperature to $-45.0^{\circ} \mathrm{C}$ at $0.5{ }^{\circ} \mathrm{C} / \mathrm{min}$ in two hours; (2) shelf temperature increased from $-45.0^{\circ} \mathrm{C}$ to $-25.0^{\circ} \mathrm{C}$ at $0.1{ }^{\circ} \mathrm{C} / \mathrm{min}$, maintaining 3 hours, and the chamber pressure held at $10 \mathrm{~Pa}$; (3) shelf temperature was increased from $-25.0^{\circ} \mathrm{C}$ to $-15.0^{\circ} \mathrm{C}$ at $0.1{ }^{\circ} \mathrm{C} / \mathrm{min}$, 
maintaining 4 hours, and the chamber pressure held at $10 \mathrm{~Pa}$; (4) shelf temperature was increased from $-15.0^{\circ} \mathrm{C}$ to $20.0^{\circ} \mathrm{C}$ at $1.0{ }^{\circ} \mathrm{C} / \mathrm{min}$, maintaining 4 hours, and the chamber pressure was raised up to $80 \mathrm{~Pa}$. In these lyophilization process conditions, the products complied with relevant provisions of the lyophilized powders for injection, meanwhile, the reproducibility was satisfactory. Post-freezing annealing had no significantly beneficial effects on shortening the freeze-drying cycle and improving the quality of GB lyophilized powder.

KEY WORDS: Ginkgolide B, formulation screening, freeze-drying process optimization, collapse temperature

\section{INTRODUCTION}

Ginkgo biloba is among the oldest living trees, with a long history of use in traditional Chinese medicine. In recent years, the extracts of ginkgo biloba leaf have been widely sold as herbal medications worldwide. The most unique components of the extracts are the terpene trilactones: ginkgolides and bilobalide. Ginkgolide B (GB) is one kind of ginkgolides, and it is the most potent inhibitor of the platelet-activating factor receptor (PAFR) (1). PAFR is a highly active mediator in the human body and has been implicated in various disease states (2) . GB has been postulated to include improvement of memory, increased blood circulation, as well as beneficial effects to sufferers of Alzheimer's disease (3,4) and cisplatin-induced ototoxicity (5).

GB is a diterpene with a cage skeleton consisting of six five-membered rings (Fig.1): a spiro[4.4]-nonane carbocyclic ring, three lactones, and a tetrahydrofuran ring, with a relative molecular weight of $424.4 \mathrm{~g} / \mathrm{mol}$ (6). GB is a white crystal, and can be dissolved in acetone, ethanol, methanol, ethyl acetate, tetrahydrofuran, dioxane, acetic acid, trifluoroacetic acid, acetonitrile, pyridine as well as dimethyl sulfoxide, and slightly dissolved in ethyl ether and water (the solubility in water of $2.5 \times 10^{-4} \mathrm{~mol} / \mathrm{L}(0.106 \mathrm{mg} / \mathrm{ml})$ ). GB cannot be dissolved in hexane, benzene, chloroform and carbon tetrachloride $(7,8)$. Under neutral or acidic conditions, all lactonic rings of GB are closed; under alkaline conditions ( $\mathrm{pH}$ at 7.5 to 12), some lactonic rings are opened because of hydrolysis. If the alkalinity increases, the majority of lactonic rings are opened to form salts. However, the GB without hydrolysis is the biologically active form, this is one of the reasons why some GB formulations can not reach the expected clinical efficacy 
original form only accounts for 34 percent at equilibrium (11).

Ginkgo biloba products are offered today in many different preparations sometimes without any kind of scientific background and control. However, in evidence-based medicine and all clinical investigations and treatments, ginkgo biloba should only be used in the form of standardized ginkgo biloba extracts (e.g. EGb $761^{\circledR}$, LI $1370^{\circledR}$ ) defined by a special composition and manufacturing process (12). Since GB is poorly soluble in water and gastric fluid environment, resulting in low dissolution and bioavailability through oral administration, it limits the development of oral preparations to some extent (13). Lyophilized formulations can be injected after reconstitution, so that higher bioavailability can be ensured (14). Furthermore, the loss of the active ingredient is reduced during the freeze-drying production. In general, lyophilized formulations are easy to transport and long-term storage. In order to develop GB to lyophilized powder for injection, the a five step procedure has been carried out in this paper: (1) solvent, surfactant, excipient and solution of PH screening for formulation; (2) process preparation: choosing GB API adding order, mixing temperature, added amount of active carbon and absorption time; (3) freeze-drying optimization of process parameters for freeze stage, primary drying stage and secondary drying stage; (4) Verification experiments of lyophilization process; (5) Effects of annealing on lyophilization rate and product quality.

\section{MATERIALS AND METHODS}

\section{Materials}

GB (the purity $\geq 98 \%$ ) was purchased from Nanjing Dierge Medical and Technological Co., Ltd.(Jiangsu, China). Tween 80, Tween 20, Tween 40, Poloxamer 188, Cremophor El, glucose, lactose, mannitol, dextran20, sucrose and L-arginine were purchased from Aladdin Reagent Database Inc. (Shanghai, China), which were analytical grades. Methanol was obtained from Xingke Solvent Inc. (Shanghai, China), which was HPLC grade. Water for injection was supplied from GMP Training Center of China Pharmaceutical University.

\section{Formulation Screening of GB Lyophilized Powder for Injection}

\section{Specification Determination}

Only several ginkgo biloba preparations were approved in China. On the basis of the ginkgo biloba injection produced by Chengdu Baiyu Pharmaceutical Co., Ltd.(Sichuan, China), each vial contains $2 \mathrm{~mL}$ solution and $10 \mathrm{mg}$ terpene lactones as active pharmaceutical ingredient (API), in 


\begin{tabular}{lccccccc}
\hline $\begin{array}{l}\text { GB con. } \\
/ \mathrm{mg} \cdot \mathrm{L}^{-1}\end{array}$ & 500 & 1000 & 2000 & 3000 & 4000 & 5000 & 6000 \\
\hline Peak areas & $291028 \pm$ & $612131 \pm$ & $1207230 \pm$ & $1793174 \pm$ & $2458279 \pm$ & $3075164 \pm$ & $\begin{array}{c}359107 \\
7 \pm 1465 \\
\end{array}$ \\
1896 & 2130 & 4213 & 6472 & 8745 & 11824 & 8
\end{tabular}

Regression equation

GB standards were accurately weighed and placed in a volumetric flask, then dissolved with methyl alcohol. The obtained solution was diluted by methyl alcohol to prepare standard solutions with different concentrations, such as $0.5 \times 10^{3} \mathrm{mg} / \mathrm{L}, 1 \times 10^{3} \mathrm{mg} / \mathrm{L}, 2 \times 10^{3} \mathrm{mg} / \mathrm{L}, 4 \times 10^{3} \mathrm{mg} / \mathrm{L}, 6 \times 10^{3}$ $\mathrm{mg} / \mathrm{L}$, then the contents of GB were determined with HPLC (Shimadzu Co., Ltd, China). The chromatographic conditions: the column was Agilent ZORBAX SB-C18 $(4.6 \times 150 \mathrm{~mm}, 5 \mu \mathrm{m})$, the column temperature was $25^{\circ} \mathrm{C}$, the mobile phase was methanol-water (50:50), the velocity of flow was $1.0 \mathrm{~mL} / \mathrm{min}$, the detection wavelength was $220 \mathrm{~nm}$, and the injection volume was $20 \mu \mathrm{L}$.

The concentrations of GB and their correspondent peak area data were shown in Table 1, the standard curve was shown in Fig. 2. The results showed that from $0.5 \times 10^{3} \mathrm{mg} / \mathrm{L}$ to $6 \times 10^{3} \mathrm{mg} / \mathrm{L}$, and three experiments were repeated at each concentration to get the standard deviation of peak area. As a result, the linear relationship between concentrations and peak areas was good. The sampling precision test was done as follows: the reference solution (the concentration of $4 \times 10^{3}$ $\mathrm{mg} / \mathrm{L}$ ) was sampled six times, and the peak areas were recorded, and RSD was $0.15 \%$ by calculation.

Table 1 GB standard curve data

Note: " $\mathrm{n}=7$ " means the number of GB concentrations to fit the regression equation of 7.

\section{Solvent Selection}

The most commonly used solvent in lyophilized powder for injection is water, but GB is poorly soluble in it. Therefore, mixed solvents were considered. Among solvents with ability to dissolve GB, ethyl alcohol, propylene glycol, glycerin, PEG 200 and PEG 400 had higher safety,

$$
y=606.49 x-1634.4, R^{2}=0.9993(n=7)
$$


co-solvents increased with their increased volume concentration. However, when volume concentrations of ethyl alcohol, propylene glycol, glycerin, PEG 200 were above 10 percent, the frozen solid could easily spray during primary drying. Because their melting point were relatively low, which were hard to be fully frozen. Only PEG 400 had relatively high melting point, and the above phenomenon did not easily happen. So PEG 400 and water for injection as the co-solvent was chosen.

\section{Solubilization Method Selection}

When poorly water-soluble drugs were prepared to lyophilized powders for injection, commonly solubilized methods included adding surfactants and latent solvents, adjusting $\mathrm{pH}$, inclusion technique, emulsified or micro-emulsification etc. when we design an experiment, in general, we should consider the operating conditions and procedure, the cost of experiment ${ }_{2}-$ the kind of equipment to be used and the easiness to carry out the experiment. In this study, according to physical and chemical properties of GB and characteristics of lyophilized powders, adding surfactants and adjusting $\mathrm{pH}$ were chosen to increase the solubility of GB because these two methods are easy to fulfill, efficiency in cost and only HPLC instrument is used for experiments, the other methods of increasing the solubility of GB will be discussed in the future.

Surfactants for injection provided by FDA include Tween 80, Tween 20, Tween 40, Poloxamer 188, Cremophor EL, etc. The concentration of the above surfactants were mixed with $2 \mathrm{mg} \mathrm{GB}$, respectively, then $1 \mathrm{~mL}$ water for injection was added, ultrasonic processing was carried out for 10 minutes. Clarities of the obtained solution containing Poloxamer 188 or Cremophor EL were better than the others. It found that moulds produced easily in the Poloxamer 188 solution. So the Cremophor EL was more suitable, and its safe dose was large (15).

GB was soluble and stable in concentrated acid, but poorly soluble in weakly acid solution. In weakly alkaline solution, its lactone rings occurred partial hydrolysis, with the increase of $\mathrm{pH}$, the more lactone rings opened. From injection aspects to consider, it was suitable to adjust the $\mathrm{pH}$ of GB solution to be acidulous or neutral. The solution (which consisted of PEG 400, Cremophor EL and water) $\mathrm{pH}$ value was around 6.0,. $\mathrm{Na}_{2} \mathrm{CO}_{3}, \mathrm{NaHCO}_{3}$, phosphate, meglumine, L-arginine, etc. could be used as the basic $\mathrm{pH}$ adjusting agents. L-arginine played an important therapeutic effect on atherosclerosis, which could promote vasodilation and angiogenesis, as well as inhibit the 


\begin{tabular}{|c|c|c|c|}
\hline excipients & $\begin{array}{c}\text { solution } \\
\text { appearance }\end{array}$ & after standing for $12 \mathrm{~h}$ & $\begin{array}{c}\text { lyophilized product } \\
\text { appearances }\end{array}$ \\
\hline glucose & $\begin{array}{l}\text { clear and } \\
\text { transparent }\end{array}$ & clear and transparent & serious collapse on one side \\
\hline lactose & $\begin{array}{l}\text { clear and } \\
\text { transparent }\end{array}$ & clear and transparent & $\begin{array}{c}\text { slight collapse and cracks on the } \\
\text { surface }\end{array}$ \\
\hline mannitol & $\begin{array}{l}\text { clear and } \\
\text { transparent }\end{array}$ & clear and transparent & intact and porous cake structure \\
\hline dextran 20 & clear and & precipitation of crystals after & shrinking into a huddle \\
\hline sucrose & $\begin{array}{l}\text { transparent } \\
\text { clear and } \\
\text { transparent }\end{array}$ & $\begin{array}{c}8 \mathrm{~h} \\
\text { precipitation of crystals after } \\
4 \mathrm{~h}\end{array}$ & $\begin{array}{l}\text { collapse near the bottom, forming } \\
\text { an inverted circular table }\end{array}$ \\
\hline
\end{tabular}

aggregation of platelets and granulocytes (16). Therefore, L-arginine was chosen as the $\mathrm{pH}$ adjusting agent.

\section{Excipient Screening}

The desired appearance of lyophilized powder should be an intact and porous cake structure. Furthermore, the color should be uniform. In order to obtain a better appearance, some excipients were added into API to provide a lyophilized skeleton. The following five excipients were used in this experiment: glucose, lactose, mannitol, dextran 20 and sucrose. The above excipients were separately added in the PEG 400 and Cremophor EL solution, and the dosage of each excipient was $6 \%(\mathrm{~g} / \mathrm{mL})$. Then solution appearance and lyophilized product appearances of above obtained solutions were compared, and the results were shown in Fig.3 and Table 2. By comprehensive comparison, mannitol as the excipient was the best because the structure by mannitol as excipient is intact and porous, that means there is no defect (no collapse, no crack on the surface, no shrink, no spray phenomenon and no collapse at the bottom etc.).

(1)


1 The GB content was determined through external standard method of HPLC, building a $\mathrm{L}_{9}\left(3^{4}\right)$

2 orthogonal table.

\section{Freeze Drying Process Optimization of GB Lyophilized Powder for Injection}

\section{Determination of Glass Transition Temperature of Maximally Freeze-concentrated Solution}

In the freeze-drying process, three stages are included, they are freezing, primary drying and secondary drying. In the freezing stage, the lowest temperature could be confirmed on the basis of freezing point (including eutectic temperature or glass transition temperature), and the highest temperature during the primary drying was confirmed on the basis of collapse temperature. Material freezing point is usually determined through electric resistance method, freeze-drying microscope observation method and differential scanning calorimetry (17).

According to the optimized formulation, the GB solution was prepared and the vials with GB solution were placed on the shelves of freeze drier (Shanghai Tofflon Co., Ltd., China). Two electrodes of the digital multi-meter were fixed on both sides in a beaker, and the solution temperature was determined by temperature probes of the freeze drier. Electric resistances of GB solution and corresponding temperatures were recorded as shown in Table 3 . Then the temperature-resistance curve was obtained from data directly and data by regression(shown in Fig. 4), the temperature at the maximum curvature was the freezing point. The fitted curve was $\mathrm{R}=$ $\mathrm{a} \times e^{b \times T}$ (where $\left.a=0.225, b=-0.102\right)$ and the computational formula was as following (18):

$$
\mathrm{k}=\left|\frac{\mathrm{R}^{\prime \prime}}{\left(1+\mathrm{R}^{\prime 2}\right)^{\frac{3}{2}}}\right|
$$

Where $\mathrm{k}$ is the slope of temperature-resistance curve, $\mathrm{R}$ is the solution resistance $(M \Omega), \mathrm{R}^{\prime}$ is the first derivative of the solution resistance, $\mathrm{R}^{\prime \prime}$ is the second derivative, $\mathrm{T}$ is the solution temperature $\left({ }^{\circ} \mathrm{C}\right)$.

There was not a fixed melting point of GB solution by DSC 204 F1 (Netzsch Geraetebau $\mathrm{GmbH}$, Germany).Therefore, where the freezing point was the glass transition temperature of maximally GB freeze-concentrated solution $\left(\mathrm{Tg}^{\prime}\right)$. By calculation, the freezing point of GB solution was $-17.6^{\circ} \mathrm{C}$, while the freezing point was determined at $-16.5^{\circ} \mathrm{C}$ through freeze-drying microscope observation method. We can see the glass transition temperature measured by two method has a $1^{\circ} \mathrm{C}$ difference, it proves that the measured transition temperature has a high accuracy. In general case, the lowest temperature during the freezing was about $10 \sim 20^{\circ} \mathrm{C}$ lower 
4

\begin{tabular}{lccccccccc}
\hline Temperature $/{ }^{\circ} \mathrm{C}$ & 20.4 & 12.5 & 6.1 & -0.2 & -6.6 & -12.3 & -16.1 & -20.4 & -26.1 \\
\hline $\begin{array}{l}\text { Electric } \\
\text { resistance } / \mathrm{M} \Omega\end{array}$ & 0.02 & 0.09 & 0.15 & 0.24 & 0.38 & 0.64 & 0.98 & 2.3 & 3.24 \\
\hline
\end{tabular}

than $\mathrm{Tg}^{\prime}$. Therefore, the lowest freezing temperature was at $-45.0^{\circ} \mathrm{C}$ to ensure the material being fully frozen.

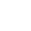

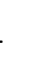
Table 3 Resistances of GB solution and corresponding temperatures
5

6

7

62

\section{Determination of Collapse Temperature}

During primary drying, if the product temperature is higher than the collapse temperature, the amorphous material will undergo viscous flow, resulting in loss of the pore structure obtained by freezing, which is defined as the collapse phenomenon by Pikal and Shah (19). Collapsed dried products generally have a high residual water content and lengthy reconstitution times and may also present a loss of functional properties. Moreover, in the pharmaceutical industry, collapse is a normally cause for rejection of the vials due to the lack of material elegance. Since a small variation of temperature can greatly modify the primary drying time as well as the dried product structure, an accurate determination of the collapse temperature is critical for the process optimization (20), the Freeze dry microscope usually is used for measuring collapse temperature. Collapse temperature of GB lyophilized powder for injection was determined by the FDCS 196 freeze-drying microscope (Linkam Scientific Instruments Ltd., UK). $2 \mu \mathrm{L}$ GB solution was taken and dropped between two glass cover slips. Then the freeze-drying stage was sealed, and an appropriate multiple objective was used to observe the solution. The solution was cooled from room temperature to $-45.0{ }^{\circ} \mathrm{C}$ at $10.0{ }^{\circ} \mathrm{C} / \mathrm{min}$, then the freeze-drying stage was moved to find the edge of the frozen solution, and the pressure in the stage maintained at about $20 \mathrm{~Pa}$. Slow heating was followed, the movement of sublimation interface was observed, to judge at what temperature it began to collapse and collapsed completely, respectively. During $-45.0^{\circ} \mathrm{C}$ to $-15.0^{\circ} \mathrm{C}$, the sublimation interface moved from the edge of the glass slide to the center, there was a very clear sublimation interface between the drying zone and freeze zone. And at $-14.0^{\circ} \mathrm{C}$, the sublimation interface became not clear and there was a small quantity of viscous flow, resulting in loss of the pore structure, meaning $-14.0^{\circ} \mathrm{C}$ was the temperature of the onset of collapse. When the temperature increased to $-13.0^{\circ} \mathrm{C}$, the more viscous flow happened near the sublimation interface, 
1 judging that $-13.0^{\circ} \mathrm{C}$ was the full collapse temperature. Heating up continually, much more

2 viscous flow happened, and all were shown in Fig. 5.Hence, the highest temperature of primary

3 drying was below $-14.0^{\circ} \mathrm{C}$.

4 Optimization of the Freeze-drying Process by Orthogonal Design

Firstly, various factors influencing GB lyophilized powder quality were confirmed from preliminary experiments, then freeze-drying process was optimized by orthogonal design. The following four items were as investigation factors: I: freezing temperature, cooling rate and duration; II: temperature changes during the primary drying, with gradient heating at $0.1{ }^{\circ} \mathrm{C} / \mathrm{min}$; III: the primary drying time and pressure; IV: the secondary drying temperature and pressure. Appearance yield and residual water content were as two evaluation indexes, building a $\mathrm{L}_{9}\left(3^{4}\right)$ orthogonal table. Residual water content was determined by V 20 Karl Fischer (METTLER TOLEDO, Switzerland). Qualified appearance criterions: it should be an intact and porous cake structure (no collapse, no crack on the surface, no shrink, no spray phenomenon and no collapse at the bottom etc.), without significant volume changes before and after lyophilization (21).

\section{RESULTS AND DISCUSSIONS}

\section{Optimized Formulation}

The formulation was optimized by an orthogonal design using the software SPSS 19.0. Factor levels are shown in Table 4, orthogonal results shown in Table 5 and variance analysis results shown in Table 6 and Table 7. For the intuitively range analysis of GB content and reconstitution time in Table 5, the range values represented the influence order of the factors. Therefore, according to the range values in Table 5, the order of four factors for GB content was $\mathrm{D}>\mathrm{B}>\mathrm{A}>$ C (A: PEG 400 concentration $(\mathrm{mL} / \mathrm{mL})$; B: Cremophor EL concentration $(\mathrm{mL} / \mathrm{mL})$; C: mannitol concentration $(\mathrm{g} / \mathrm{mL})$; D: solution $\mathrm{pH})$. As for the evaluation index of GB content, the higher mean value under one factor $(A, B, C, D)$ was required, so $D_{1} B_{2} A_{1} C_{1}$ was chosen as the optimized formulation. Similarly, for the reconstitution time of GB lyophilized powder, the influence order of the factors was $B>A>D>C$. But the shorter reconstitution time was better, so $B_{3} A_{3} D_{3} C_{1}$ or $B_{3} A_{3} D_{3} C_{2}$ was chosen as the optimized formulation.

As shown in Table 6, through the variance analysis of GB content, only factor D had a significant influence $(\mathrm{p}<0.01)$, obtaining the highest GB content when factor D in level 1 in Table 5 (The GB content increased from $2.5 \times 10^{-4} \mathrm{~mol} / \mathrm{L}(0.106 \mathrm{mg} / \mathrm{ml})$ to 1.914 
$1(2 \times(94.7 \%+96.2 \%+95.8 \%) / 3) \mathrm{mg} / \mathrm{ml})$. As shown in Table 7, factor A, B, D had significant effects

2 on GB lyophilized powder reconstitution time. And in Table 5, when factor A and B were in level

33 , the reconstitution time was the shortest. On both GB content and reconstitution time respects by

4 the variance analyses in Table 6 and Table 7, factor $\mathrm{C}$ had no significant effect on measurements.

5 But the amount of mannitol was chosen $8 \%(\mathrm{~g} / \mathrm{mL})$, the obtained GB lyophilized powder was the

6 most intact and porous by comparing $6 \%(\mathrm{~g} / \mathrm{mL})$ and $10 \%(\mathrm{~g} / \mathrm{mL})$. Through comprehensive

7 analyses of the two evaluation indexes, the optimized formulation was $\mathrm{D}_{1} \mathrm{~B}_{3} \mathrm{~A}_{3} \mathrm{C}_{2}$, i.e. $\mathrm{pH}$ at 6.5 ,

8 Cremophor EL in an amount of 16\% (mL/mL), PEG 400 in an amount of 9\% $(\mathrm{mL} / \mathrm{mL})$, and 9 mannitol in an amount of $8 \%(\mathrm{~g} / \mathrm{mL})$.

10

Table 4 Factor levels

\begin{tabular}{ccccc}
\hline \multirow{2}{*}{ levels } & \multicolumn{5}{c}{ factors } \\
\cline { 2 - 5 } & $\mathrm{A} / \%$ & $\mathrm{~B} / \%$ & $\mathrm{C} / \%$ & $\mathrm{D}$ \\
\hline 1 & 5 & 8 & 6 & 6.5 \\
2 & 7 & 12 & 8 & 7.0 \\
3 & 9 & 16 & 10 & 7.5 \\
\hline
\end{tabular}

11

12

Table 5 Orthogonal design results of formulation screening

\begin{tabular}{|c|c|c|c|c|c|c|c|}
\hline & \multirow[t]{2}{*}{ No. } & \multicolumn{4}{|c|}{ levels } & \multicolumn{2}{|c|}{ evaluation indexes } \\
\hline & & A & B & $\mathrm{C}$ & $\mathrm{D}$ & $\begin{array}{c}\text { GB } \\
\text { content } / \%\end{array}$ & $\begin{array}{c}\text { reconstitution } \\
\text { time } / \mathrm{s}\end{array}$ \\
\hline & 1 & 1 & 1 & 1 & 1 & 94.7 & 61 \\
\hline & 2 & 1 & 2 & 2 & 2 & 86.6 & 58 \\
\hline & 3 & 1 & 3 & 3 & 3 & 36.0 & 48 \\
\hline & 4 & 2 & 1 & 2 & 3 & 36.8 & 52 \\
\hline & 5 & 2 & 2 & 3 & 1 & 96.2 & 55 \\
\hline & 6 & 2 & 3 & 1 & 2 & 87.2 & 48 \\
\hline & 7 & 3 & 1 & 3 & 2 & 85.3 & 54 \\
\hline & 8 & 3 & 2 & 1 & 3 & 38.3 & 46 \\
\hline & 9 & 3 & 3 & 2 & 1 & 95.8 & 45 \\
\hline \multirow{5}{*}{ GB contents } & mean 1 & 72.433 & 72.267 & 73.400 & 95.567 & & \\
\hline & mean 2 & 73.400 & 73.700 & 73.067 & 86.367 & & \\
\hline & mean 3 & 73.133 & 73.000 & 72.500 & 37.033 & & \\
\hline & Range & 0.967 & 1.433 & 0.900 & 58.534 & & \\
\hline & mean 1 & 55.667 & 55.667 & 51.667 & 53.667 & & \\
\hline \multirow{3}{*}{$\begin{array}{l}\text { reconstitution } \\
\text { time }\end{array}$} & mean 2 & 51.667 & 53.000 & 51.667 & 53.333 & & \\
\hline & mean 3 & 48.333 & 47.000 & 52.333 & 48.667 & & \\
\hline & Range' & 7.334 & 18.667 & 0.666 & 5.000 & & \\
\hline
\end{tabular}


Table 6 Variance analysis results of GB contents

\begin{tabular}{cccccc}
\hline $\begin{array}{c}\text { sources of } \\
\text { variance }\end{array}$ & $\begin{array}{c}\text { sum of square } \\
\text { of deviations }\end{array}$ & $\begin{array}{c}\text { degree of } \\
\text { freedom }\end{array}$ & F ratio & $\begin{array}{c}\text { F critical } \\
\text { value }\end{array}$ & P value \\
\hline A & 1.496 & 2 & 1.205 & 19.000 & \\
B & 3.082 & 2 & 2.481 & 19.000 & \\
D & 5944.569 & 2 & 4786.287 & 99.000 & $<0.01$ \\
(C(error) & 1.242 & 2 & 1.000 & & \\
\hline
\end{tabular}

Note: If $\mathrm{F}$ ratio $>\mathrm{F}$ critical value, $\mathrm{P}<0.01$, representing the difference was significant. The effect of

$4 \mathrm{C}$ (mannitol concentration )on GB content could be neglected, and its range value in Table 5 was

5 minimum, so the factor $\mathrm{C}$ was chosen as error term.

6

7

Table 7 Variance analysis results of GB lyophilized powder reconstitution time

\begin{tabular}{cccccc}
\hline $\begin{array}{c}\text { sources of } \\
\text { variance }\end{array}$ & $\begin{array}{c}\text { sum of square } \\
\text { of deviations }\end{array}$ & $\begin{array}{c}\text { degree of } \\
\text { freedom }\end{array}$ & F ratio & $\begin{array}{c}\text { F critical } \\
\text { value }\end{array}$ & P value \\
\hline A & 80.889 & 2 & 90.989 & 19.000 & $<0.05$ \\
B & 118.222 & 2 & 132.983 & 19.000 & $<0.05$ \\
D & 46.889 & 2 & 52.744 & 19.000 & $<0.05$ \\
C(error) & 0.889 & 2 & & & \\
\hline
\end{tabular}

8 Note: If F ratio $>\mathrm{F}$ critical value, $\mathrm{P}<0.01$, representing the difference was significant. The effect of

$9 \mathrm{C}$ (mannitol concentration ) on reconstitution time could be neglected, and its range value in Table 5 was minimum, so the factor $\mathrm{C}$ was chosen as error term.

\section{Confirmation of GB Solution Preparation Process}

GB stability is affected by GB adding order, preparing GB solution temperature, amount of activated carbon and its adsorption time experiments. For example, the order of adding GB API will affect the transparent time of mixed solution; high temperature of preparing GB solution will cause the GB decompose; the over amount of active carbon added and more adsorption time of active carbon will cause the GB content decrease. So, GB adding order, preparing GB solution temperature, amount of activated carbon and its adsorption time experiments were set up one factor at a time to study their effects on GB stability. GB solution preparation process was confirmed as followings: $2.0 \mathrm{mg} / \mathrm{mL}$ GB was taken and added into the mixed solvent of $16 \%$ $(\mathrm{mL} / \mathrm{mL})$ Cremophor El and 9\% (mL/mL) PEG 400, via ultrasonic treatment for 10 minutes. Then prescribed water for injection were added in it under electromagnetic stirring, and $8 \%(\mathrm{~g} / \mathrm{mL})$ mannitol was added the obtained solution, L-arginine was used to adjust the $\mathrm{pH}$ at 6.5 . And $0.05 \%$ 
1 (g/mL) activated carbon was added into the above solution, then under electromagnetic stirring $(1000 \mathrm{r} / \mathrm{min})$ for 35 minutes at $40.0^{\circ} \mathrm{C}$, which was filtered through $0.22 \mu \mathrm{m}$ PVDF membrane, finally filled and freeze-dried.

\section{Optimized Freeze-drying Parameters}

Through above, freeze-drying parameter optimization was carried out with SPSS 19.0 using an orthogonal design . Factor levels are shown in Table 8, orthogonal design results are shown in Table 9, and variance analysis results are shown in Table 10 and Table 11. For the intuitively range analysis of appearance yield and residual water in Table 9, the range values represented the influence order of factors. According to the range values in Table 9, considering the appearance yields, the influence order of the factors was I $>$ II $>$ III $>$ IV (I: freezing temperature, cooling rate and duration; II: temperature changes during the primary drying, with gradient heating at $0.1{ }^{\circ} \mathrm{C}$ /min; III: the primary drying time and pressure; IV: the secondary drying temperature and pressure). As for the evaluation index of appearance yield, the higher mean value under one factor (I, II, III, IV) was required, so $\mathrm{I}_{1} \mathrm{II}_{3} \mathrm{III}_{1} \mathrm{IV}_{1}$ was chosen as the optimized freeze-drying parameters. Similarly, for the residual water content, the order of the factors was II $>$ IV $>$ I $>$ III. Since the lower residual water content of GB lyophilized powder the better, $\mathrm{II}_{3} \mathrm{IV}_{3} \mathrm{I}_{1} \mathrm{III}_{3}$ was chosen as the optimized freeze-drying parameters.

As shown in Table 10, through the variance analysis of appearance yields, the factor I and II had significant effects ( $\mathrm{P}$ value $<0.05$ ). And in Table 9, when factor I was in level 1 and factor II in level 3, the appearance yield was the highest. As shown in Table 11, factor II and IV had significant effects on the residual water content. When factor II was in level 3 and factor IV in level 3, the residual water content of GB lyophilized powder was the lowest. On both appearance yield and residual water content respects, factor III had no significant effects. In fact, it is well known that shorter drying time can shorten the whole freeze-drying cycle and improve the productivity for enterprises, so $\mathrm{III}_{1}(12 \mathrm{~h}, 10 \mathrm{~Pa})$ was chosen as the duration of primary drying.

Based on the above considerations, $\mathrm{I}_{1} \mathrm{II}_{3} \mathrm{III}_{1} \mathrm{IV}_{3}$ was the optimized freeze-drying parameters.

Table 8 Factor levels

\begin{tabular}{|c|c|c|c|c|c|}
\hline \multirow{2}{*}{ levels } & \multicolumn{5}{|c|}{ factors } \\
\hline & & I & II & III & IV \\
\hline 1 & $-45.0^{\circ} \mathrm{C}, 0.5$ & ${ }^{\circ} \mathrm{C} / \mathrm{min}, 2 \mathrm{~h}$ & $-45.0^{\circ} \mathrm{C} \rightarrow-15.0^{\circ} \mathrm{C}$ & $12 \mathrm{~h}, 10 \mathrm{~Pa}$ & $20.0^{\circ} \mathrm{C}, 20 \mathrm{~Pa}$ \\
\hline 2 & $-45.0^{\circ} \mathrm{C}, 1.0$ & ${ }^{\circ} \mathrm{C} / \mathrm{min}, 2 \mathrm{~h}$ & $-45.0^{\circ} \mathrm{C} \rightarrow-30.0^{\circ} \mathrm{C}$ & $15 \mathrm{~h}, 10 \mathrm{~Pa}$ & $20.0^{\circ} \mathrm{C}, 50 \mathrm{~Pa}$ \\
\hline
\end{tabular}




\begin{tabular}{|c|c|c|c|c|}
\hline & & $-30.0^{\circ} \mathrm{C} \rightarrow-15.0^{\circ} \mathrm{C}$ & & \\
\hline 3 & $-45.0^{\circ} \mathrm{C}, 2.0^{\circ} \mathrm{C} / \mathrm{min}, 2 \mathrm{~h}$ & $\begin{array}{l}-45.0^{\circ} \mathrm{C} \rightarrow-25.0^{\circ} \mathrm{C} \\
-25.0^{\circ} \mathrm{C} \rightarrow-15.0^{\circ} \mathrm{C}\end{array}$ & $18 \mathrm{~h}, 10 \mathrm{~Pa}$ & $20.0^{\circ} \mathrm{C}, 80 \mathrm{~Pa}$ \\
\hline
\end{tabular}

2

3

Table 9 Orthogonal design results of freeze-drying process

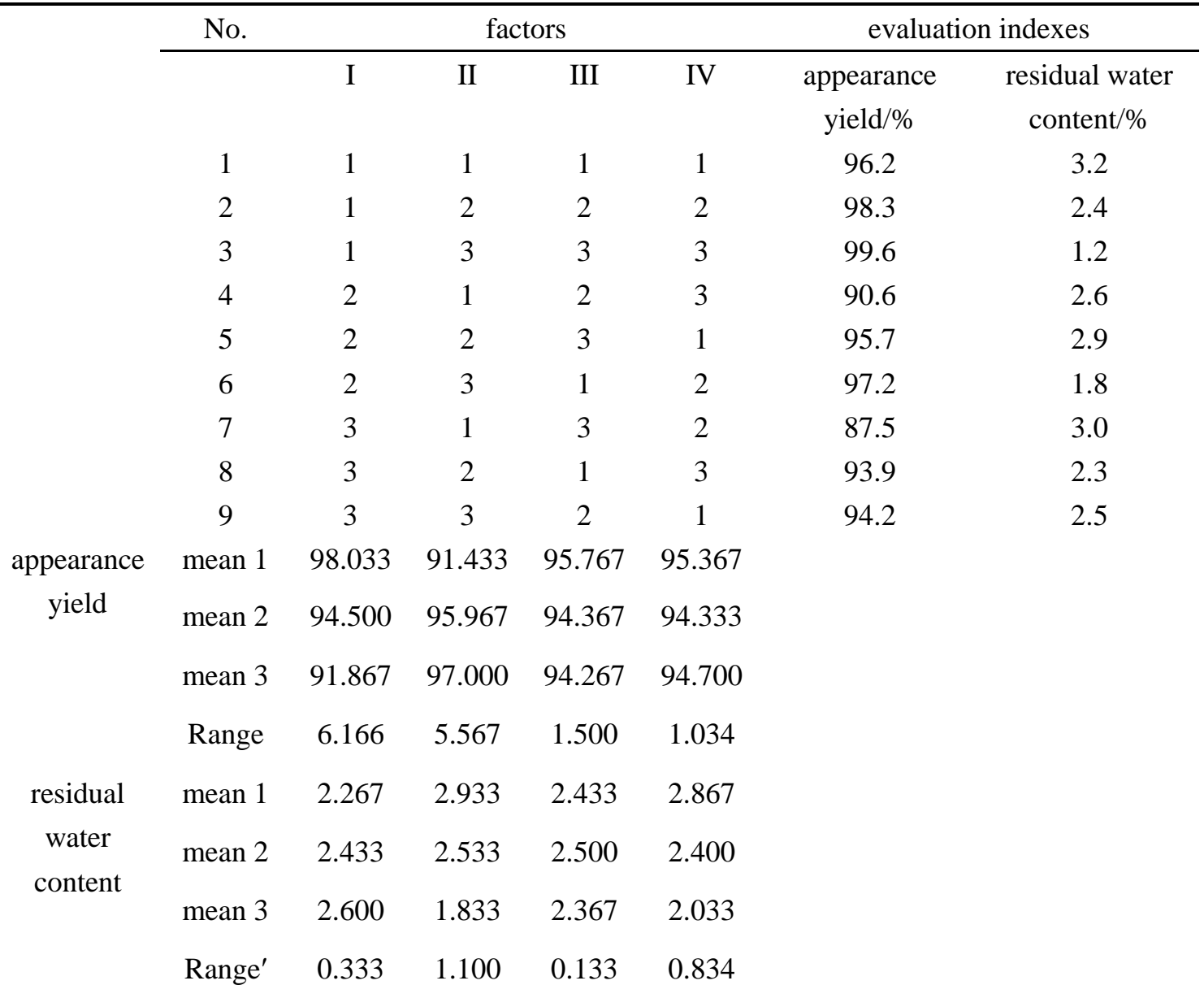

4

5

Table 10 Variance analysis results of appearance yields

\begin{tabular}{cccccc}
\hline $\begin{array}{c}\text { sources of } \\
\text { variance }\end{array}$ & $\begin{array}{c}\text { sum of square } \\
\text { of deviations }\end{array}$ & $\begin{array}{c}\text { degree of } \\
\text { freedom }\end{array}$ & F ratio & $\begin{array}{c}\text { F critical } \\
\text { value }\end{array}$ & P value \\
\hline I & 57.447 & 2 & 34.880 & 19.000 & $<0.05$ \\
II & 52.607 & 2 & 31.941 & 19.000 & $<0.05$ \\
III & 4.220 & 2 & 2.562 & 19.000 & \\
IV(error) & 1.647 & 2 & & & \\
\hline
\end{tabular}

6 Note: If $\mathrm{F}$ ratio $>\mathrm{F}$ critical value, $\mathrm{P}<0.01$, representing the difference was significant. The range

7 value of factor IV in Table 9 on appearance yields was minimum, so it was chosen as error term.

8

9

Table 11 Variance analysis results of residual water content

\begin{tabular}{cccccc}
\hline $\begin{array}{c}\text { sources of } \\
\text { variance }\end{array}$ & $\begin{array}{c}\text { sum of square } \\
\text { of deviations }\end{array}$ & $\begin{array}{c}\text { degree of } \\
\text { freedom }\end{array}$ & F ratio & $\begin{array}{c}\text { F critical } \\
\text { value }\end{array}$ & P value \\
\hline
\end{tabular}




\begin{tabular}{cccccc}
\hline I & 0.167 & 2 & 6.185 & 19.000 & \\
II & 1.860 & 2 & 68.889 & 19.000 & $<0.05$ \\
IV & 1.047 & 2 & 38.778 & 19.000 & $<0.05$ \\
III(error) & 0.027 & 2 & & & \\
\hline
\end{tabular}

1

2

3

4

5

Note: If $\mathrm{F}$ ratio $>\mathrm{F}$ critical value, $\mathrm{P}<0.01$, representing the difference was significant. The range value of factor III in Table 9 on residual water content was minimum, so it was chosen as error term.

\section{Verification of Lyophilization Process}

According to the previously optimized process, three batches of $300 \mathrm{~mL}$ GB solution were prepared and filled into $7 \mathrm{~mL}$ vials, and each vial contained $2 \mathrm{~mL}$ solution. These 100 vials were lyophilized in accordance with the optimized freeze-drying parameters, with the freeze-drying cycle of 20.7 hours. All products were intact and porous, the mean reconstitution time was $(41 \pm 5)$ seconds, and the mean residual water content was $(1.18 \pm 0.14) \%$. It showed that the optimized formulation and freeze-drying process could meet the specifications of lyophilized powder for injection, and with a good reproducibility.

\section{Effects of Annealing on Lyophilization Rate and Product Quality}

Some researches reported that annealing could improve lyophilization rate and shorten the freeze-drying cycle $(22,23)$. Hence, experiments were carried out to study the effects of annealing on lyophilization rate and product quality. The frozen solution was heated to above the eutectic temperature or glass transition temperature, but below the melting temperature held for a specified duration and then frozen again. In the experiments, GB solution has a glass transition temperature of $-17.6^{\circ} \mathrm{C}$, so the annealing temperature was set as two different temperatures of $-14.5^{\circ} \mathrm{C}$ and $-8.0^{\circ} \mathrm{C}$

\section{Annealing at $-14.5^{\circ} \mathrm{C}$}

At normal atmospheric pressure, the GB solution was frozen from room temperature to $-45.0^{\circ} \mathrm{C}$, and then immediately heated to $-14.5^{\circ} \mathrm{C}$. This temperature was_maintained constant for one hour, so that the lyophilization process continued following the above mentioned optimized freeze-drying parameters. By annealing at $-14.5^{\circ} \mathrm{C}$, the period of primary drying was shortened of about three hours, so that the whole cycle was 21.7 hours long. Compared to the GB lyophilized powder without annealing, the products annealed at $-14.5^{\circ} \mathrm{C}$ were looser, and the apertures were larger, even showing some cavities, and slight collapse occurred for about 1 percent of the 
material, as shown in Fig. 6. In terms of residual water content, GB content, related substances and $\mathrm{pH}$, both of the two had no significant differences.

Annealing at $-8.0^{\circ} \mathrm{C}$

Like the above annealing treatment, another batch of GB solution was annealed at $-8.0^{\circ} \mathrm{C}$ for one hour. The period of primary drying was shortened to about three hours, the freeze-drying cycle was 22.2 hours and the whole process parameters was automatically recorded by the lyophilizer. GB lyophilized powder in all vials shrinked up severely and had difficult in reconstitution, shown in Fig. 7. Compared to the GB lyophilized powder without annealing, the products annealed at $-14.5^{\circ} \mathrm{C}$ had no significant differences in terms of residual water content, GB content, related substances and $\mathrm{pH}$.

To find the reason of annealing collapse at $-14.5^{\circ} \mathrm{C}$ and $-8.0^{\circ} \mathrm{C}$, decreasing freeze temperature and extending its time, decreasing the highest temperature and pressure of the primary drying measures were taken, only decreasing the highest temperature of the primary drying was helpful to improve the collapse. It could be deduced that the annealing treatment might improve the collapse temperature because of the changes of ice crystal morphology and size distribution. Thus, qualified GB lyophilized powder for injection could be obtained according to the optimized process, without annealing.

\section{CONCLUSION}

In this paper, the optimal formulation of GB lyophilized powder for injection was determined alongside with the optimised conditions for the complete formulation process. Firstly, solvent, solubilizer, excipient and $\mathrm{pH}$ screen were screened, PEG 400 in an amount of $9 \%(\mathrm{~mL} / \mathrm{mL})$, Cremophor EL in an amount of $16 \%(\mathrm{~mL} / \mathrm{mL})$, mannitol in an amount of $8 \%(\mathrm{~g} / \mathrm{mL})$ and $\mathrm{pH}$ at 6.5 were determined to make the solubility of GB improved of more than 18 times (from $0.106 \mathrm{mg} / \mathrm{ml}$ to $1.914 \mathrm{mg} / \mathrm{ml}$ ). Secondly, the preparing process was carried out by using a one factor at a time experimental design; thirdly, by orthogonal design, the optimized formulation was obtained. The optimized operation schedule for the process was: freezing from room temperature to $-45.0^{\circ} \mathrm{C}$ at $0.5{ }^{\circ} \mathrm{C} / \mathrm{min}$, then holding for 2 hours; in the primary drying stage, heating the temperature from $-45.0^{\circ} \mathrm{C}$ to $-25.0^{\circ} \mathrm{C}$ at $0.1^{\circ} \mathrm{C} / \mathrm{min}$, and then holding for 3 hours; heating the temperature from $-25.0^{\circ} \mathrm{C}$ to $-15.0^{\circ} \mathrm{C}$ at $0.1^{\circ} \mathrm{C} / \mathrm{min}$, and holding for 4 hours; in the whole primary drying stage 
1 the chamber pressure was kept at $10 \mathrm{~Pa}$; in the secondary drying stage, heating the 2 temperature from $-15.0^{\circ} \mathrm{C}$ to $20.0^{\circ} \mathrm{C}$ at $1{ }^{\circ} \mathrm{C} / \mathrm{min}$, and holding for 4 hours, with the chamber 3 pressure kept to $80 \mathrm{~Pa}$. Then, the verification batch experiments have been carried out according to 4 the above optimized protocol. A very satisfactory quality for GB lyophilized power for injection 5 was achieved. Furthermore, post-freezing annealing process analysis has been carried out. The 6 relevant_discovery was that annealing is not beneficial for the processsince it did not allow to 7 reduce the freeze-drying cycle and, what was worse, it caused some collapse on the material.

8 Therefore, a complete process of formulation preparation of GB lyopilized power for injectionhas 9 been given. This study would provide references for optimization technology of GB lyophilized powder for injection.

\section{ACKNOWLEDGMENTS}

This work is supported by Jiangsu oversea research \& training program for university prominent young \&middle aged teachers and presidents. Also the authors would like to thank Professor Wang Suilou for the help in the experiment work and the suggestions to improve the paper, and thanks to Dr Wang Haixiang for help in the experiments; also appreciated Donfulong limited Company and help provided by engineers Liu, many thanks to Professor Xu Li's help on the experiments. Finally, the authors would like to acknowledge the support provided by UCL during Dr. Yu's visit to London.

\section{REFERENCES}

1. Belayev L, Khoutorova L, Atkins K, GordonWC, Alvarez-BuillaJ, BazanNG. LAU-0901, a novel platelet-activating factor antagonist, is highly neuroprotective in cerebral ischemia. Exp Neurol. 2008; 214(2):253-8.

2. Strømgaard K, Saito DR, Shindou H, Ishii H, Shimizu T, Nakanishi K. Ginkgolide derivatives for photolabeling studies: preparation and pharmacological evaluation. JMed Chem. 2002; 45(18):4038-46. 
3. Michelangelo Mancuso, Fabio Coppedè, Luigi Murri, Gabriele Siciliano. Mitochondrial cascade hypothesis of Alzheimer's disease: myth or reality? Antioxid \& Redox Signaling. 2007; 9(10):1631-46.

4. Polich J, Gloria R. Cognitive effects of a Ginkgo biloba/vinpocetine compound in normal adults: systematic assessment of perception, attention and memory. Hum PsychopharmCli. 2001; 16(5):409-16.

5. Weijun Ma, Juan Hu, Ying Cheng, Junli Wang, Xiaotong Zhang, Min Xu. Ginkgolide B protects against cisplatin-induced ototoxicity: enhancement of Akt-Nrf2-HO-1 signaling and reduction of NADPH oxidase. Cancer Chemother Pharmacol. 2015; 75(5):949-59.

6. Okabe K, Yamada K, Yamamura S, Takada S. Ginkgolides. J Chem Soc. 1967;2201-6.

7. Michael T. Crimmins, Jennifer M. Pace, Philippe G. Nantermet, Agnes S. Kim-Meade, James B. Thomas, Scott H. Watterson, Allan S. Wagman. The total synthesis of ( \pm )-Ginkgolide. J. Am. Chem. Soc. 2000;122(25):8453-63.

8. Koji Nakanishi. Ginkgolides and bilobalide: their physical, chromatographic and spectroscopic properties. Bioorg Med Chem. 2005;13(17):5001-12.

9. Defaye. Use of natural cyclodextrins and their derivatives for the solubilization of platelet anti- aggregating agents from the family of ginkgolides: USA, 5798432 [P], 1998-8-25.

10. Xuejing Li, Kui Yang, Gang Du, Liang Xu, KeLan. Understanding the regioselective hydrolysis of ginkgolide B under physiological environment based on generation, detection, identification, and semi-quantification of the hydrolyzed products. Anal Bioanal Chem. 2015; 407(26):7945-56.

11. Xuejing Li, Yu-Qing Wang, Jing Yang, Xue Fan, Ling Wang, Kui Yang, Ke Lan. Semi-quantitative determination of mono-carboxylate forms of ginkgolide B in plasma by UPLC-MS. Anal Bioanal Chem. 2015;407(14):4121-9.

12. Christian Ude, Manfred Schubert-Zsilavecz, Mario Wurglics. Ginkgo biloba extracts: a review of the pharmacokinetics of the active ingredients. ClinPharmacokinet. 2013;52(9):727-49.

13. Jie Zhao, Ting Geng, Qi Wang. Pharmacokinetics of ginkgolide B after oral administration of three different ginkgolide B formulations in beagle dogs. Molecules. 2015,20(1),20031-41.

14. Julia Christina Kasper, Gerhard Winter, Wolfgang Friess. Recent advances and further challenges in lyophilization. Eur J Pharm Biopharm. 2013;85(2):162-9.

15. Raymond C. Rowe, Paul J. Sheskey, Marian E. Quinn. Handbook of Pharmaceutical Excipients (Sixth Edition) [S]. APhA Publications. 2003.

16. Boost KA, AuthMKH, Woitaschek D, Kim HS, HilgardP, NadalinS, BlahetaRA. Long-term production of major coagulation factors and inhibitors by primary human hepatocytes in vitro: perspectives for clinical application. Liver Int. 2007;27(6):832-44.

17. Eva Meister, Henning Gieseler. Freeze-dry microscopy of protein/sugar mixtures: drying behavior, interpretation of collapse temperatures and a comparison to corresponding glass transition data. J Pharm Sci. 2009;98 (9):3072-87.

18. Qingliang Cui, YumingGuo, Zhengwei Cheng. Measurement of the eutectic point and melting point of the freeze-dried materials based on electric resistance method. Transactions of the Chinese Society for Agricultural Machinery. 2008;39(5):65-9. 
19. Pikal MJ, Shah S. The collapse temperature in freezedrying: Dependence on measurement methodology and rate of water removal from the glassy phase. Int. J. Pharm. 1990; 62:165-86.

20. Fonseca F, Passot S,Cunin O, Marin M. Collapse temperature of freeze-dried lactobacillus bulgaricussuspensions and protective media.Biotechnol. Prog. 2004;20:229-38.

21. Louis Rey, Joan C. May. Freeze Drying/lyophilization of pharmaceutical and biological products (third edition). UK: Informa Healthcare. 2010:1-28.

22. James A. Searles, John F. Carpenter, Theodore W. Randolph. Annealing to optimize the primary drying rate, reduce freezing-induced drying rate heterogeneity, and determine $\mathrm{Tg}^{\prime}$ in pharmaceutical lyophilization. J Pharm Sci. 2001; 90(7):860-71.

23. Smith G, Arshad MS, Polygalov E, Ermolina I. An application for impedance spectroscopy in the characterisation of the glass transition during the lyophilization cycle: the example of a $10 \%$ w/v maltodextrin solution. Eur J Pharm Biopharm. 2013;85(3):1130-40.

*Corresponding author: Ying YU, email: yyingazz@ 163.com.

Answer to Reviewer 1:

Thanks for your helpful suggestion to improve the paper. We have corrected the misunderstood according to your comments. On original page 6 and page 7, changed from "dissolution status" to "solution appearance", and from "lyophilized solution appearances" to "lyophilized product appearance". 
Fig.1 The structure of Ginkgolide B

Fig. 2 The standard curve between concentrations and peak areas of GB

Fig. 3 Lyophilized product appearances of five excipients

Fig. 4 The temperature-resistance curve of GB solution

Fig. 5 Collapse process of $\mathrm{GB}$ lyophilized powder: a(at-15 $\left.{ }^{\circ} \mathrm{C}\right), \mathrm{b}\left(\right.$ at $\left.-14^{\circ} \mathrm{C}\right), \mathrm{c}\left(\mathrm{at}-13^{\circ} \mathrm{C}\right), \mathrm{d}\left(\mathrm{at}-12^{\circ} \mathrm{C}\right)$.

Fig. 6 The left vial was the appearance of GB lyophilized powder without annealing

Fig. 7 The left vial was the appearance of GB lyophilized powder without annealing 


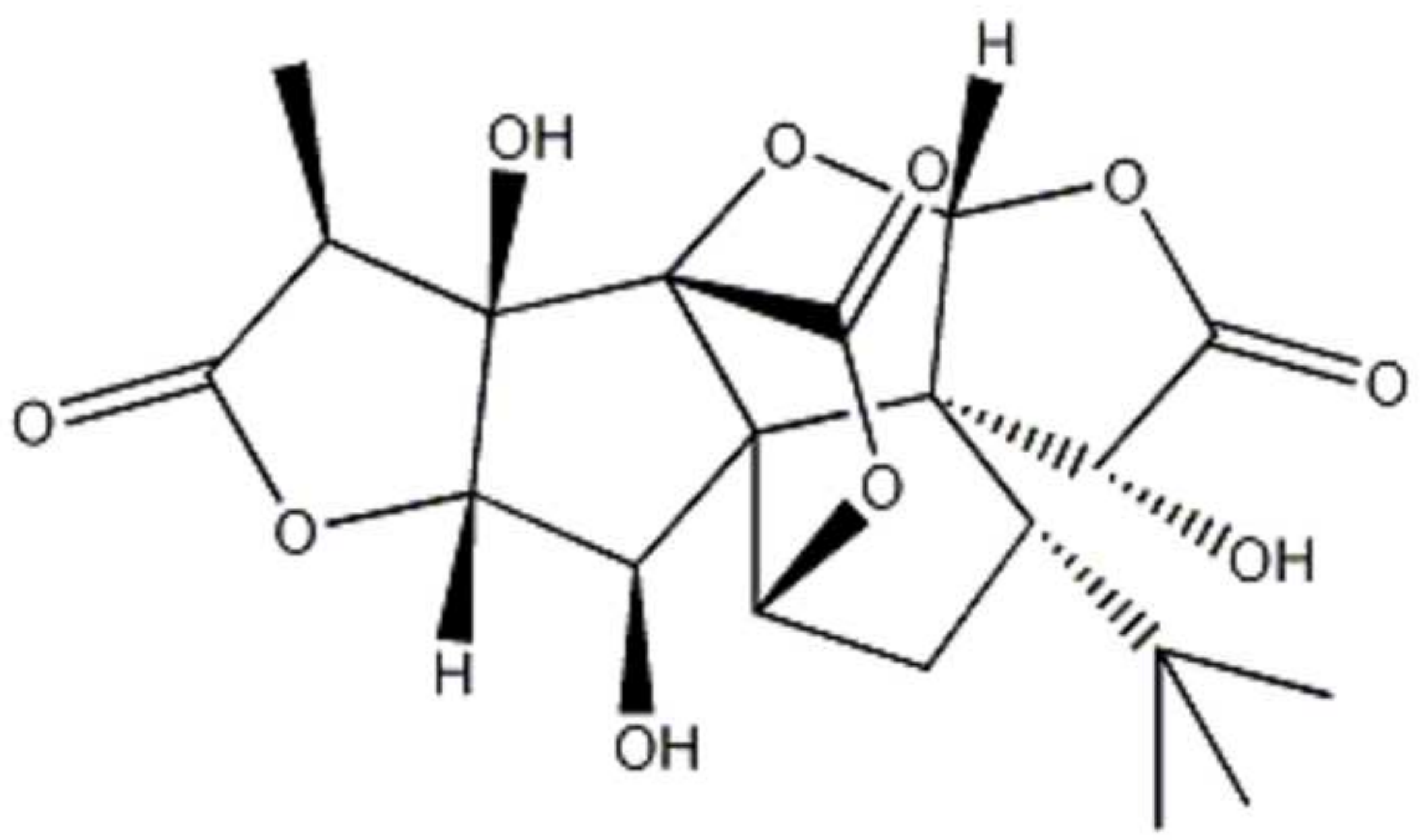




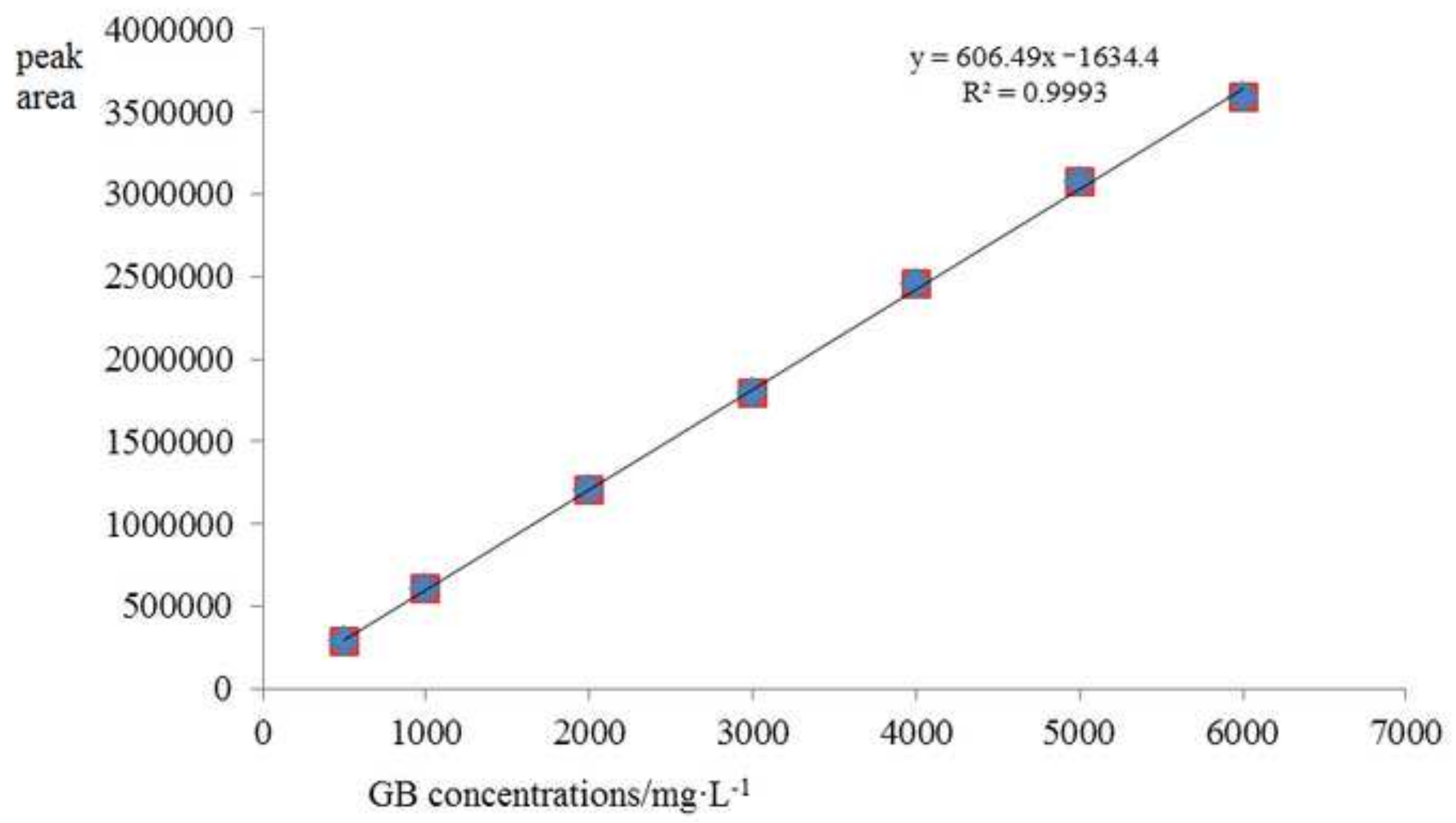




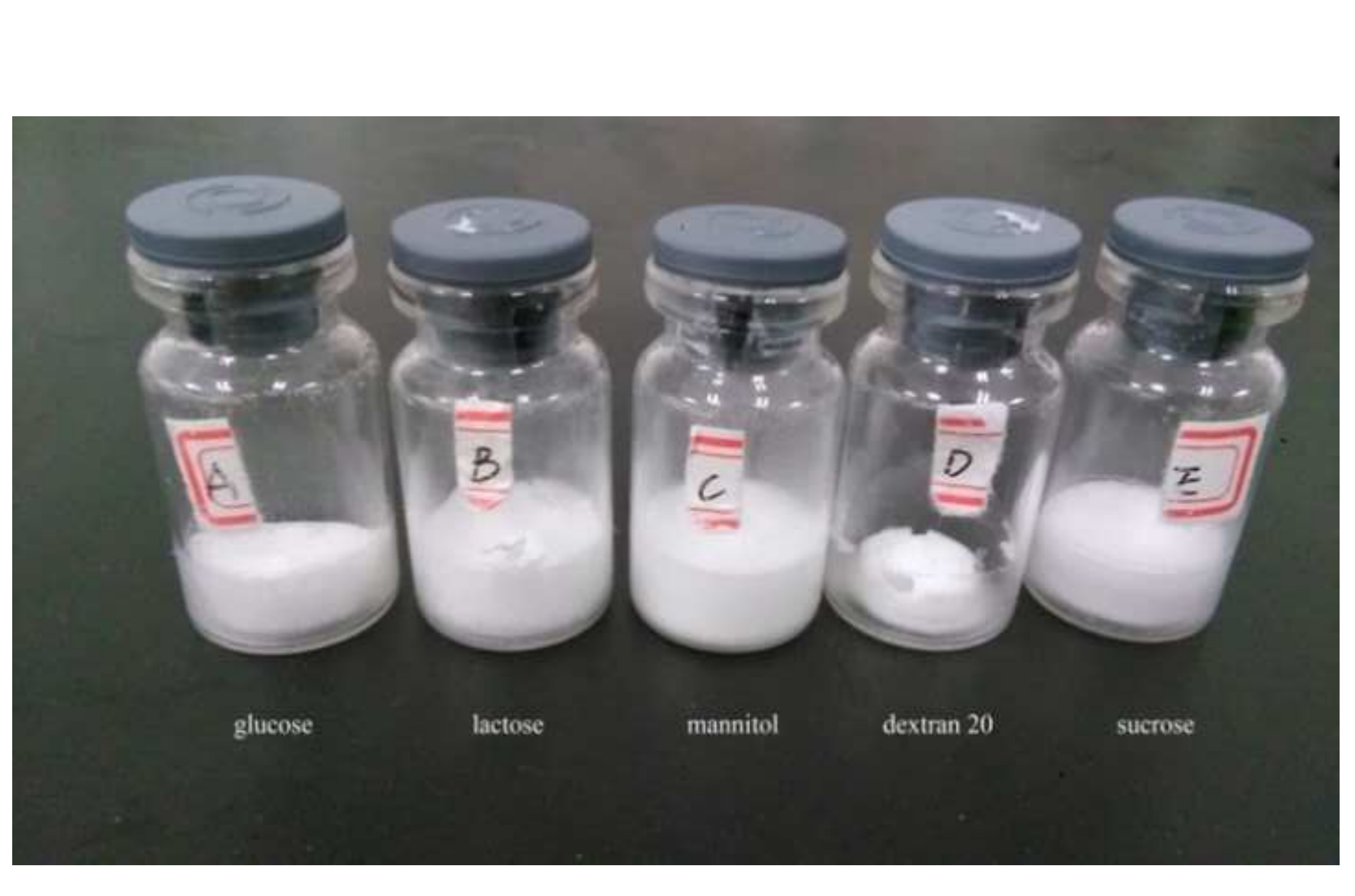

.

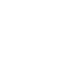




\section{Resistance /M $\Omega$}

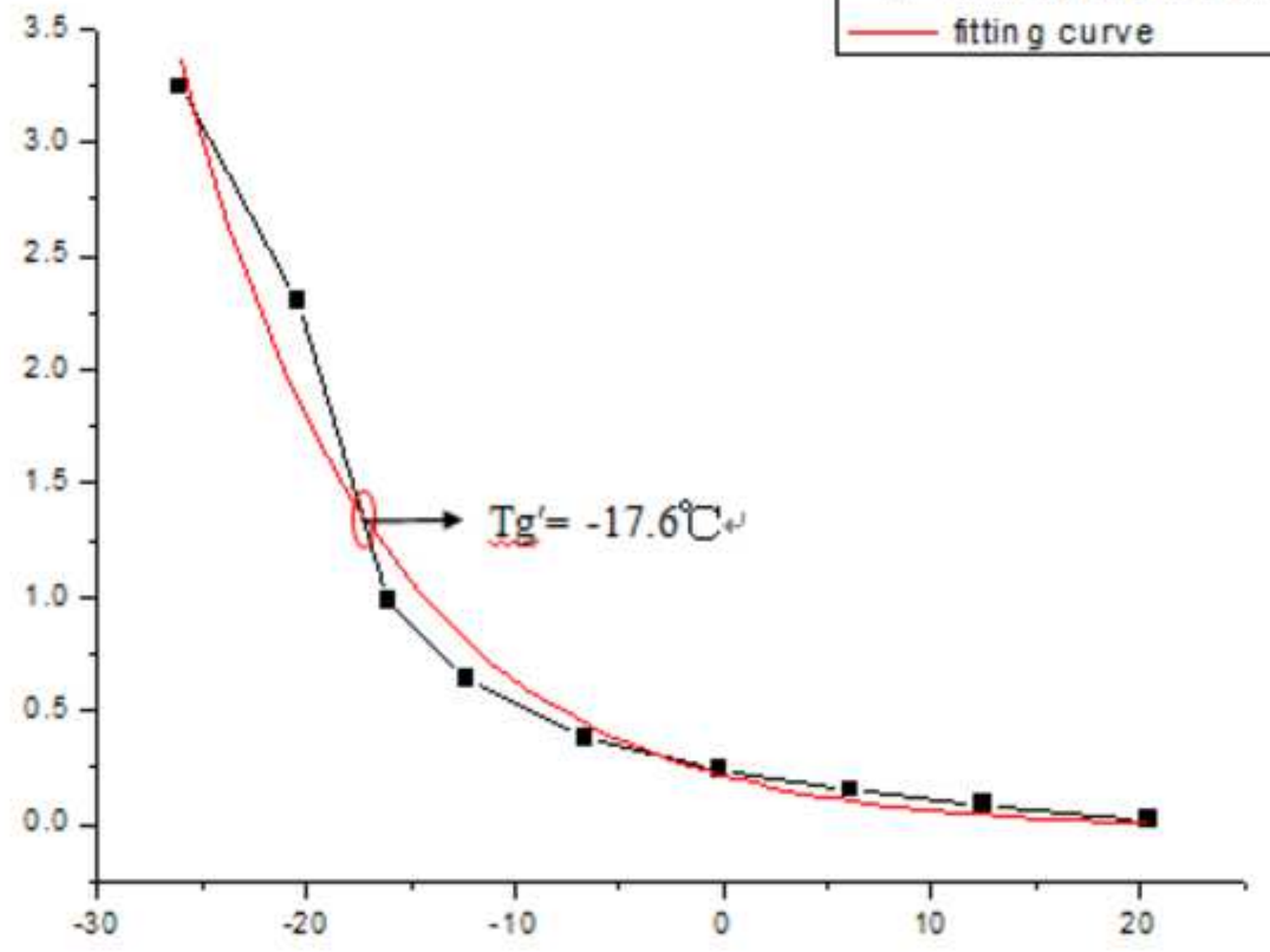

Temperature $/{ }^{\circ} \mathrm{C}$

$-m-$ continu ous line of data fittin g curve 


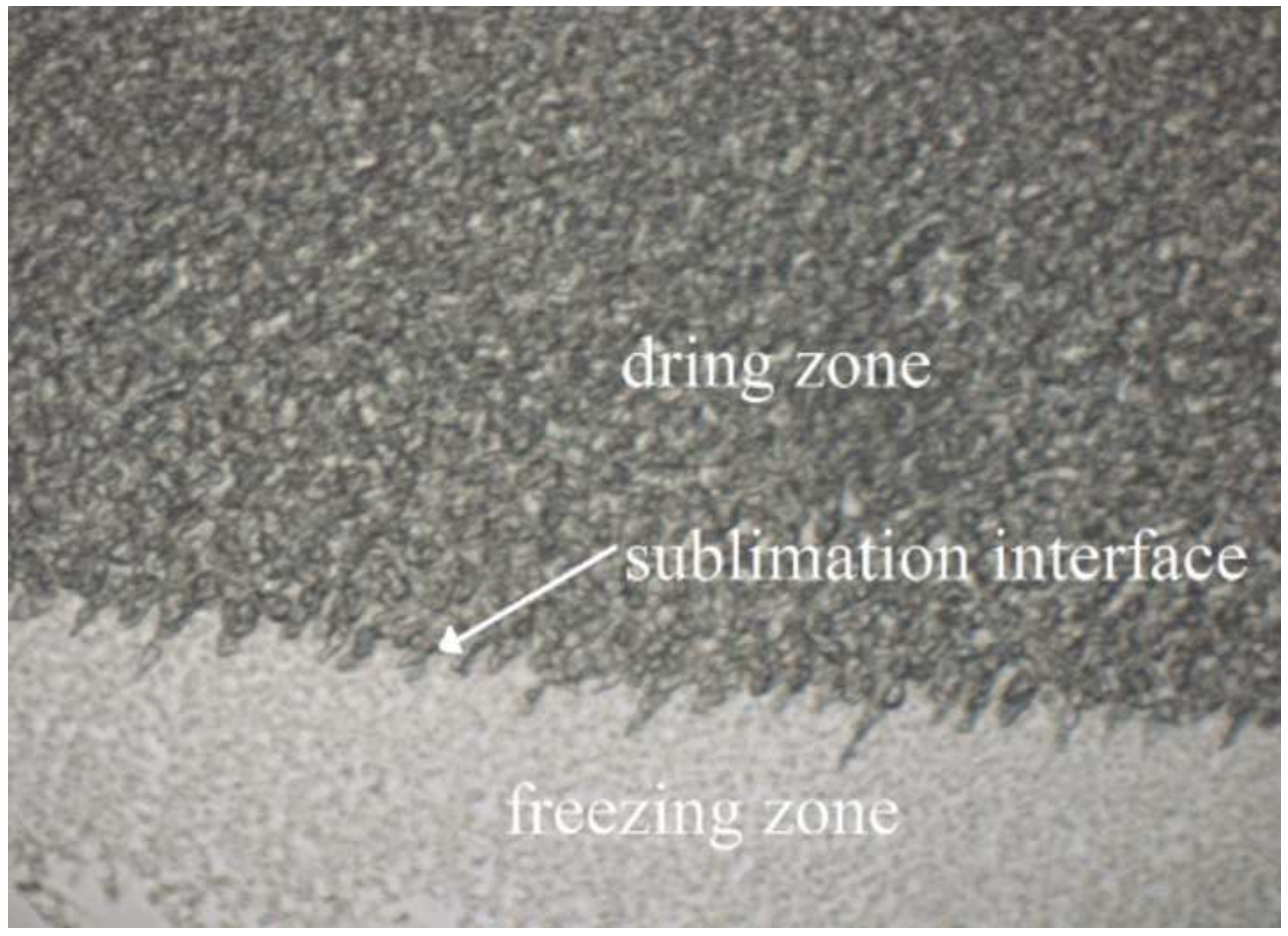

\section{dring zone}

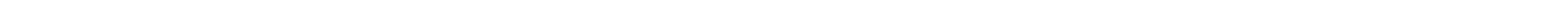



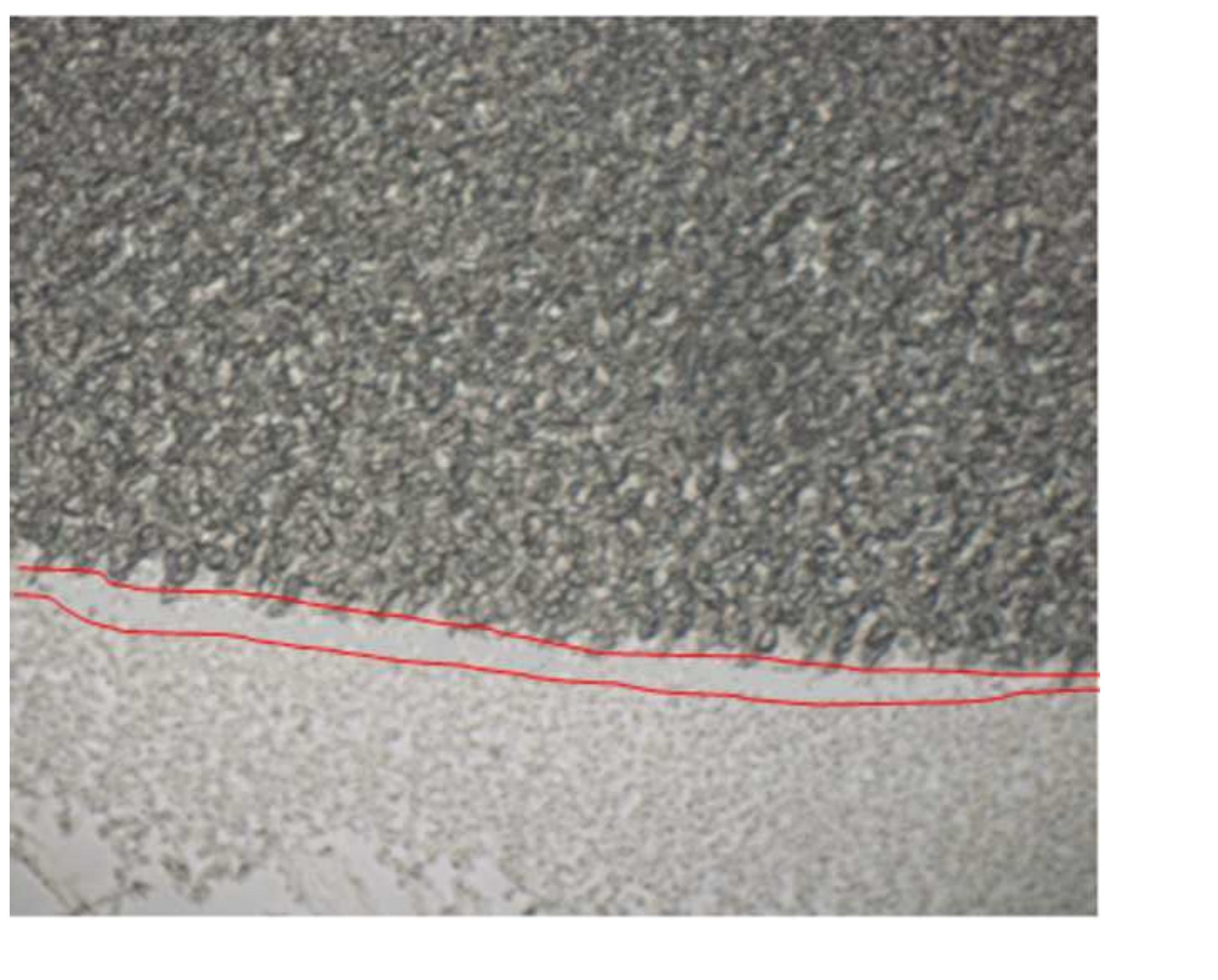

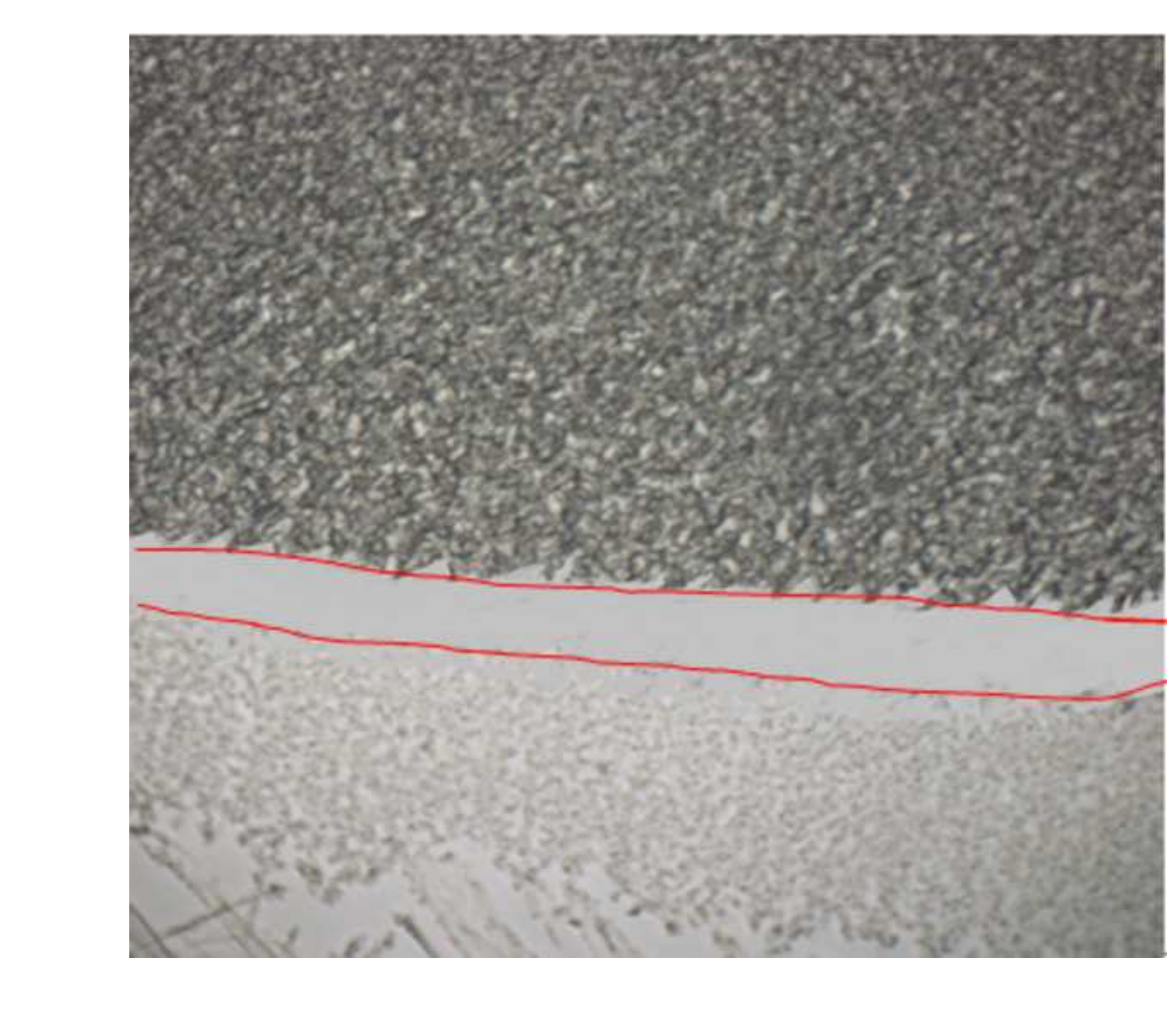

\section{$\underline{\underline{s}}$}

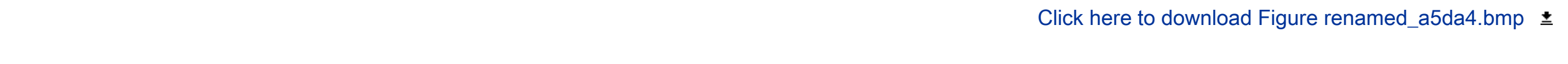



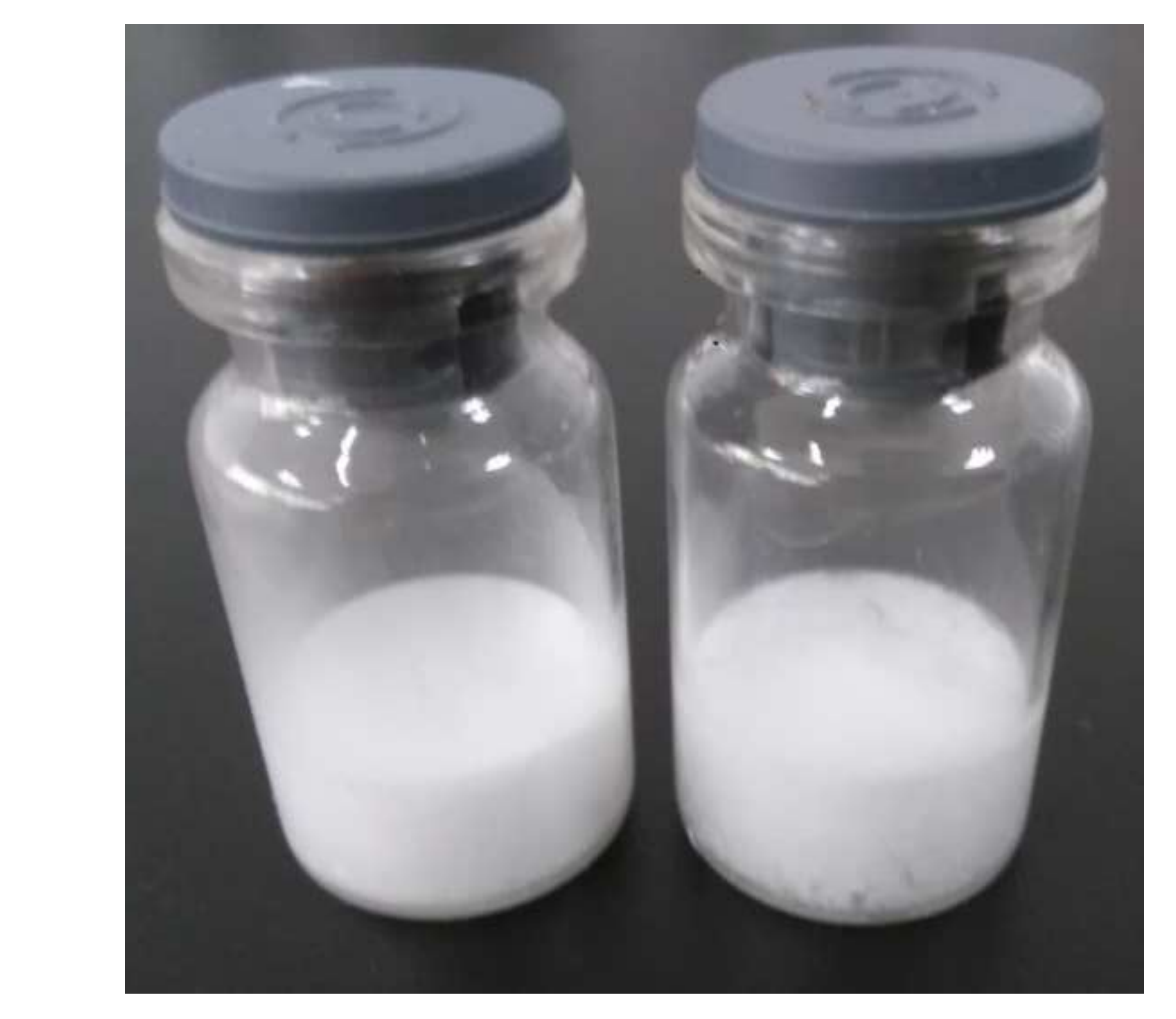
Figure 6
Click here to download Figure Fig. 6.bmp $\underline{\underline{ }}$
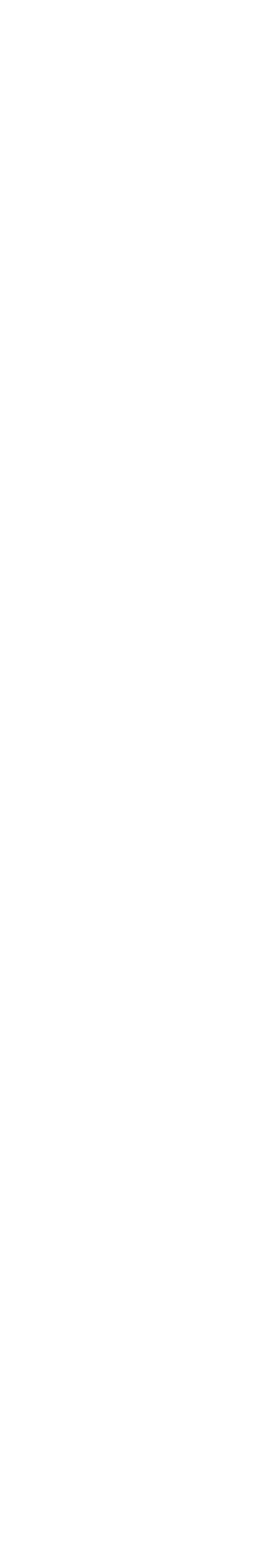
Figure 7

Click here to download Figure Fig. 7.bmp $\underline{\underline{ }}$
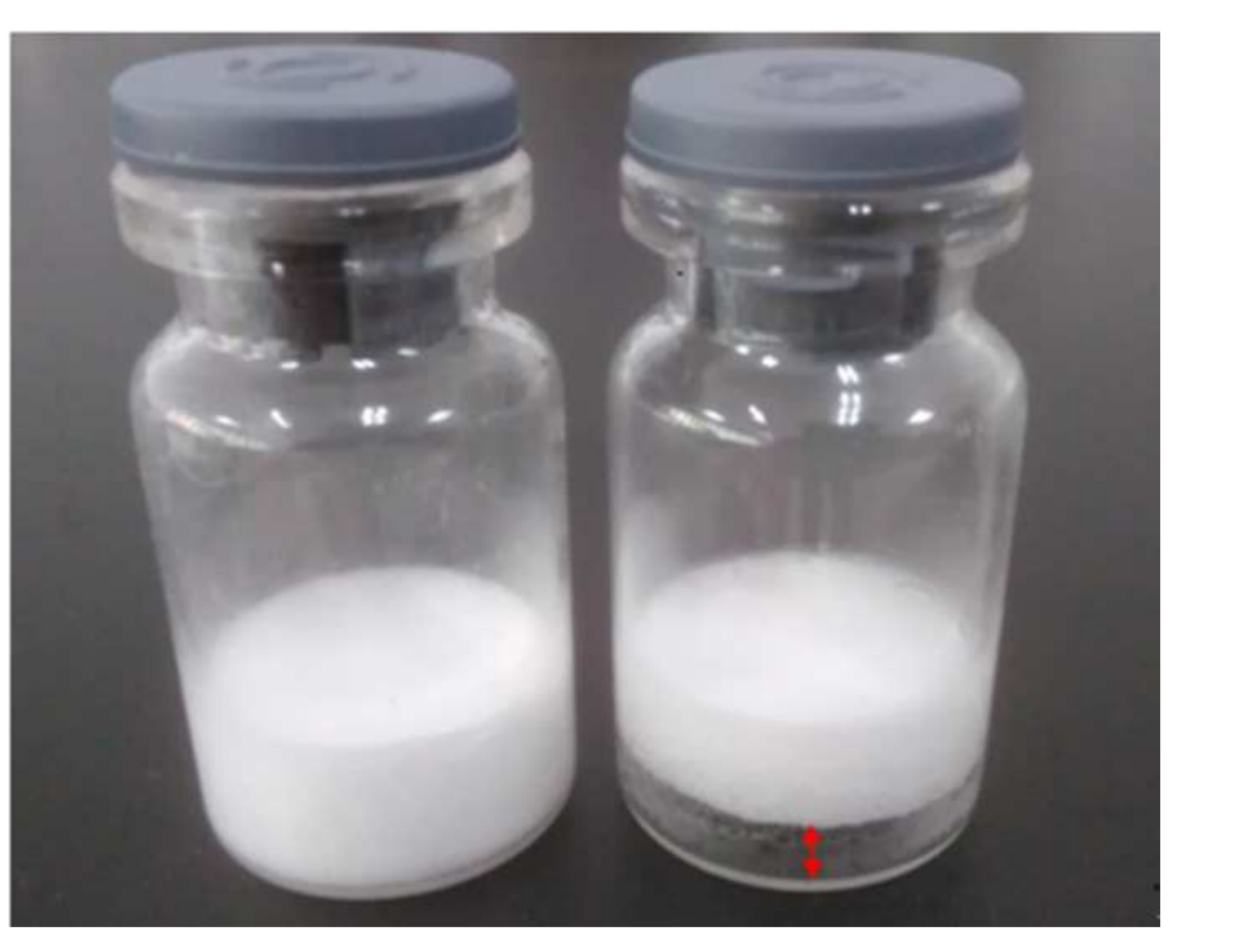
Click here to access/download

Author Supplementary Files (excel, video, etc) paper figures.rar 


\section{American Association of Pharmaceutical Scientists Transfer of Copyright Agreement}

Journal: $\square$ The AAPS Journal or $\square$ AAPS PharmSciTech

Title: formulation cropning and fropze-drving nronocc ontimization of Ginknolide $R$ lvonhilized nowder for iniertion

Author(s) name(s): Daichun Liu Federico Galvanin Ying Yu

Corresponding Author's name, address, affiliation and email: Ying YU, 24 Tongjiaxiang, Nanjing, Jiangsu province,China.

China Pharmaceutical University. email: yyingazz@163.com

The transfer of copyright gives AAPS the right to develop, promote, distribute, sell, and archive a body of scientific works in the United States and throughout the world (for government employees: to the extent transferable). The Author hereby grants and assigns to AAPS all rights in and to Author's work in and contributions to the Work. In connection with this assignment, the Author acknowledges that AAPS will have the right to print, publish, create derivative works, and sell the Work throughout the world, all rights in and to all revisions or versions or subsequent editions of the Work in all languages and media throughout the world, and shall be the sole owner of the copyright in the Work throughout the world. AAPS shall register the Work with the Copyright Office of the United States in its own name within four months after first publication.

If the Author is an employee of the U.S. Government and performed this work as part of their employment, the contribution is not subject to U.S. copyright protection. If the work was performed under Government contract, but the Author is not a Government employee, AAPS grants the U.S. Government royalty-free permission to reproduce all or part of the contribution and to authorize others to do so for U.S. Government purposes. If any of the above Authors on this agreement is an officer or employee of the U.S. Government reference will be made to this status in the signature.

An author may self-archive his/her accepted manuscript on his/her personal website provided that acknowledgement is given to the AAPS publication and a link to the published article on the journal website is inserted. An author may also deposit the accepted manuscript in a repository 12 months after publication in the journal, provided that acknowledgement is given to the AAPS publication and a link to the published article on the journal website is inserted. The Author must ensure that the publication by AAPS is properly credited and that the relevant copyright notice is repeated verbatim.

The Author reserves the following rights: (a) All proprietary rights other than copyrights, such as patent rights, (b) The right to use all or part of this article, including tables and figures in future works of their own, provided that the proper acknowledgment is made to the Publisher as copyright holder, and (c) The right to make copies of this article for his/her own use, but not for sale.

I warrant and represent that the Work does not violate any proprietary or personal rights of others (including, without limitation, any copyrights or privacy rights); that the Work is factually accurate and contains no matter libelous or otherwise unlawful; that I have substanxtially participated in the creation of the Work and that it represents my original work sufficient for me to claim authorship. I further warrant and represent that I have no financial interest in the subject matter of the Work or any affiliation with an organization or entity with a financial interest in the subject matter of the Work, other than as previously disclosed to the Association.

I have the consent of each author to transfer and assign any and all right, title, and interest; including copyright of the article referenced above. I hereby assign and transfer to the American Association of Pharmaceutical Scientists copyright and all rights under it. I further confirm that this article has not been published elsewhere, nor is it under consideration by any other publisher. 
For applicable government employees only:

(Author Name), an Author on this paper, is an employee of and, by law, is not allowed to assign copyright. As corresponding author, I therefore consent below to have this article published without transfer of copyright.

Signature: Ying YU Date: 2017.5 .5

After completion of this form, please either mail the original signed form to the AAPS Editorial Office at the address below; fax the signed form to AAPS at +1.703.243.9532; or include the signed form in your manuscript submission. 